\title{
In vitro pro-inflammatory enzyme inhibition and anti-oxidant potential of selected Sri Lankan medicinal plants
}

\author{
Hettiarachchige Dona Sachindra Melshandi Perera', Jayanetti Koralalage Ramani Radhika Samarasekera1*, \\ Shiroma Mangalika Handunnetti ${ }^{2}$, Ovitigala Vithanage Don Sisira Jagathpriya Weerasena², \\ Hasitha Dhananjaya Weeratunga ${ }^{1}$, Almas Jabeen ${ }^{3}$ and Muhammad Iqbal Choudhary ${ }^{4}$
}

\begin{abstract}
Background: The extracts of the ten selected Sri Lankan medicinal plants have been traditionally used in the treatment of inflammatory mediated diseases. The extracts were investigated for anti-inflammatory and anti-oxidant potential in vitro to identify bio-active extracts for further chemical characterization.

Methods: In vitro anti-inflammatory activities of total ethanol extracts were investigated measuring the inhibitory activities of four pro-inflammatory enzymes, arachidonate-5- lipoxygenase (A5-LOX), hyaluronidase (HYL), xanthine oxidase $(\mathrm{XO})$ and inducible nitric oxide (iNO) synthase. Cytotoxicity of extracts were determined by MTT assay. Oxidative burst inhibition (OBI) on human whole blood (WB) and isolated polymorphoneutrophils (PMNs) was carried out for a selected bio-active extract. Anti- oxidant activities of the extracts were determined by 2,2-diphenyl1-picrylhydrazyl (DPPH) free radical scavenging, ferric reducing antioxidant power (FRAP), ferrous ion chelation (FIC) and oxygen radical absorbance capacity (ORAC) assays. Total polyphenol and total Flavonoid contents of the extracts were also determined. The most active plant extract was analysed using Gas chromatography-Mass spectrometry (GC-MS) and High Performance Liquid Chromatography (HPLC).

Results: The ethanol bark extract of Flacourtia indica showed the highest A5-LOX $\left(I C_{50}: 22.75 \pm 1.94 \mathrm{~g} / \mathrm{mL}\right), X O$ $(70.46 \pm 0.18 \% ; 250 \mu \mathrm{g} / \mathrm{mL})$ and iNOs inhibitory activities on LPS- activated raw 264.7 macrophage cells (38.07 $\pm 0.93 \%$; $500 \mu \mathrm{g} / \mathrm{mL}$ ) with promising OBI both on WB ( $\left(C_{50}: 47.642 .32 \mu \mathrm{g} / \mathrm{mL}\right)$ and PMNs $\left(I C_{50}: 5.020 .38 \mu \mathrm{g} / \mathrm{mL}\right)$. The highest HYL inhibitory activity was showed by the leaf extracts of Barathranthus nodiflorus $(42.31 \pm 2.00 \% ; 500 \mu \mathrm{g} / \mathrm{mL})$ and Diospyros ebenum $(41.60 \pm 1.18 \% ; 500 \mu \mathrm{g} / \mathrm{mL})$. The bark and leaf extracts of Callophyllum innophyllum $\left(I C_{50}: 6.99 \pm 0.02 \mu \mathrm{g} / \mathrm{mL}\right)$ and Symplocus cochinchinesis $\left(I_{50}: 9.85 \pm 0.28 \mu \mathrm{g} / \mathrm{mL}\right)$ showed promising DPPH free radical scavenging activities. The GC-MS analysis of ethanol bark extract of $F$. indica showed the presence of two major bio-active compounds linoleic acid ethyl ester and hexadecanoic acid, ethyl ester (> 2\% peak area). The HPLC analysis showed the presence polyphenolic compounds.
\end{abstract}

Conclusion: The ethanol bark extract of $F$. indica can be identified as a potential candidate for the development of anti-inflammatory agents, which deserves further investigations. The bio-active plant extracts may be effectively used in the applications of cosmetic and health care industry.

Keywords: Anti-inflammatory, Enzyme inhibition, Anti-oxidant, Medicinal plants, F. indica, Gas chromatography-mass spectrometry, High performance liquid chromatography

\footnotetext{
* Correspondence: radhika@iti.lk

${ }^{1}$ Industrial Technology Institute (ITI), 363, Bauddhaloka Mawatha, Colombo

07, Sri Lanka

Full list of author information is available at the end of the article
}

(c) The Author(s). 2018 Open Access This article is distributed under the terms of the Creative Commons Attribution 4.0 International License (http://creativecommons.org/licenses/by/4.0/), which permits unrestricted use, distribution, and reproduction in any medium, provided you give appropriate credit to the original author(s) and the source, provide a link to the Creative Commons license, and indicate if changes were made. The Creative Commons Public Domain Dedication waiver (http://creativecommons.org/publicdomain/zero/1.0/) applies to the data made available in this article, unless otherwise stated. 


\section{Background}

In Sri Lanka, medicinal plants have always been used and still remain a major source in the treatment of number of diseases including inflammatory and oxidative-stress associated chronic diseases. Free radicals can be either beneficial or deleterious to the body depending on the level. The excess levels of free radicals will cause damage to most cellular macromolecules such as proteins (enzymes), lipids and DNA leading to a condition called oxidative stress [1]. Oxidative stress has been recognized as a key factor in the pathogenesis of many diseases including inflammatory diseases [2]. The excess of reactive oxygen species (ROS) generated will lead to inflammation by stimulating cytokines and activation of pro-inflammatory enzymes such as lipoxygenase, hyaluronidase, inducible nitric oxide synthase and xanthine oxidase [3]. Lipoxygenases are capable of generating lipid mediators such as leukotrines and prostaglandins, which can provoke several inflammatory diseases such as bronchial asthma, allergic rhinitis, cardiovascular diseases, rheumatoid arthritis and certain types of cancer [4]. Hyaluronidase will lead to degranulation of mast cells and release inflammatory mediators leading to several pathological conditions including rheumatoid arthritis [5]. Upon activation of inflammatory cells, inducible nitric oxide synthase (iNOs) will generate excessive amount of nitric oxide (NO), which can cause inflammation [6]. Xanthine oxidases also play a major role in the metabolic disease called gout, which is closely associated with inflammation and some other inflammatory mediated diseases due to the formation of free radicals during the catalytic function of the enzyme. It is evident that these pro-inflammatory enzymes play an important role in the pathogenesis of inflammation via different pathways. Hence, inhibition of these enzymes is considered as targets for the management of diseases associated with oxidative stress and inflammation [7].

Oxidative burst is characterized by the production and rapid release of reactive oxygen species (ROS) from immune cells, mainly by neutrophils. Though it is considered to play an important role as a defense mechanism in phagocytosis, the higher levels of ROS released during the oxidative burst has been identified to cause severe tissue injury and inflammation. Therefore inhibition of oxidative burst has been recognized as an interesting strategy in the research arena of anti-inflammatory drug research [8]. Anti-oxidants also play an important role in the management of inflammation. The efficacy of antioxidants and anti-inflammatory drugs derived from medicinal plants in the management of inflammatory diseases has been extensively documented. In this concern, medicinal plants are considered as valuable sources of potential therapeutic agents. A number of modern drugs have been isolated from medicinal plants based on the traditional use. There is an emerging interest in the use of natural products mainly those derived from medicinal plants in therapeutic applications [9]. In Sri Lanka, the practice of Ayurveda and traditional system of medicine has been implemented systematically for more than two thousand years to treat various diseases including inflammatory mediated diseases. Around 1414 of plant species including several endemic species have been used for the treatment and prevention of diseases. Among them, around 200 species are in general use and of them, nearly 50 species have been identified as heavily used plant species in Ayurveda and traditional system of medicine. With the estimated annual consumption of 2.2 million $\mathrm{Kg}$, the potential for commercial exploitation of medicinal plants has risen high [10]. In the existing scenario of emerging global interest for natural products of high therapeutic potential, exploring bio-activities of Sri Lankan medicinal plants is of great importance and high demand to support traditional claims as well as to discover unexploited bio-active properties. Moreover, the bio-assay guided isolation of bio-active compounds from identified bio-active medicinal plant extracts may come up with more effective and safer therapeutic agents against various diseases including inflammatory diseases and other oxidative stress associated chronic diseases. Also the bioactive ingredients are of high commercial potential in health care and pharmaceutical industries.

Based on this rationale, we investigated A5-LOX, hyaluronidase, xanthine oxidase, nitric oxide production and oxidative burst inhibitory properties along with anti-oxidant capacities of ten selected Sri Lankan medicinal plants, which have been used in the traditional system of medicine in the management of diseases, associated with inflammation (Table 1).

\section{Methods}

\section{Chemicals and equipment}

A5-LOX (soybean), linoleic acid, baicalein, hyaluronic acid potassium salt (human umbilical cord), hyaluronidase (bovine testes), calcium chloride, sodium hydroxide, p-Dimethylaminobenzaldehyde (PDMAB), sodium borate, tannic acid, xanthine oxidase (bovine milk), xanthine, allopurinol, Dulbecco's modified Eagle's medium (DMEM), fetal calf serum (FCS), bacterial lipopolysaccharide (LPS), trypsin, 3-(4,5-dimethylthiazol-2-yl)-2,5-diphenyltetrazoliumbromide (MTT), NG-Monomethyl-L-argininepdimethylamino benzaldehyde (NMMA), $\mathrm{HBSS}^{++}$(Hanks Balanced Salt Solution, containing calcium chloride and magnesium chloride) [Sigma, St. Louis, USA], serum opsonized zymosan (SOZ) [Fluka, Buchs, Switzerland], HBSS $^{-}$(Hanks Balanced Salt Solution without calcium chloride and magnesium chloride),folin-ciocalteu reagent, gallic acid, quercetin, ethylenediaminetetraacetic acid disodium salt (EDTA-Na $)_{2}$, dimethylsulfoxide (DMSO), 
Table 1 Traditional uses of ten Sri Lankan medicinal plants

\begin{tabular}{|c|c|c|c|}
\hline Plant name/(FAMILY) & $\begin{array}{l}\text { Local name/English } \\
\text { name }\end{array}$ & $\begin{array}{l}\text { Part used in the study/ } \\
\text { Voucher specimen No. }\end{array}$ & Traditional uses \\
\hline Sphaeranthus indicus L. (Asteraceae) & $\begin{array}{l}\text { Mudumahana/East India } \\
\text { Globe Thistle }\end{array}$ & Leaf/SEL/15/11 & $\begin{array}{l}\text { Swelling in the neck, acute laryngitis and } \\
\text { bronchitis, piles [42]. }\end{array}$ \\
\hline Acronychiapedunculata L. (Rutaceae) & $\begin{array}{l}\text { Ankenda/Claw flowered } \\
\text { laurel. }\end{array}$ & Leaf/APL/15/15 & Skin diseases, rheumatism, ulcers asthma [43]. \\
\hline $\begin{array}{l}\text { Calophyllum innophyllum } \\
\text { Linn.(Clusiaceae) }\end{array}$ & $\begin{array}{l}\text { Domba/Alexandrian } \\
\text { laurel }\end{array}$ & Bark/CIB/15/21 & Skin diseases, piles, sore eyes, migraine [44]. \\
\hline $\begin{array}{l}\text { Symplocos cochinchinesis (Lour.) S. } \\
\text { Moore. (Symplocaceae) }\end{array}$ & Sewalabombu/Lodh tree & Bark/SCB/15/27 & $\begin{array}{l}\text { Leprosy, tumors, menorrhagia, inflammation } \\
\text { and uterine problems [45]. }\end{array}$ \\
\hline $\begin{array}{l}\text { Tinospora cordifolia (Willd.) } \\
\text { (Menispermaceae) }\end{array}$ & $\begin{array}{l}\text { Rasakinda/heartleaf } \\
\text { moonseed }\end{array}$ & Bark/TCB/15/32 & $\begin{array}{l}\text { Skin diseases, Jaundice, Diabetes, rheumatic } \\
\text { pain, syphilis [46]. }\end{array}$ \\
\hline $\begin{array}{l}\text { Flacourtia indica (Burm.f. Merr.) } \\
\text { (Flacourica) }\end{array}$ & $\begin{array}{l}\text { Uguressa/Governor's } \\
\text { Plum }\end{array}$ & Bark/FIB/15/34 & $\begin{array}{l}\text { Rheumatoid arthritis, gout, intermittent fever } \\
{[40,47] \text {. }}\end{array}$ \\
\hline Leucus zeylanica L. (Lamiaceae) & $\begin{array}{l}\text { Gata thumba/Ceylon } \\
\text { slitwort }\end{array}$ & Leaf/LZL/15/41 & Jaundice, scorpion, snake bite [48]. \\
\hline $\begin{array}{l}\text { Barathranthus nodiflorus Thw. } \\
\text { (Loranthaceae) }\end{array}$ & Pilila & Leaf/BNL/15/44 & Bone fractures [49]. \\
\hline $\begin{array}{l}\text { Diospyros ebenum J.Koenig ex Retz } \\
\text { (Ebenaceae) }\end{array}$ & Kaluwara/Ceylon ebony & Leaf/DEL/15/47 & Snake bite, diarrhoea, ulcers, biliousness [32]. \\
\hline $\begin{array}{l}\text { Argyreia populifolia Choisy } \\
\text { (Convolvulaceae) }\end{array}$ & Elephant creeper & Leaf/APL/15/48 & Swellings [50]. \\
\hline
\end{tabular}

2,2-diphenyl-2-picryl-hydrazyl

(DPPH), 6-hydroxy-2-5-7-8-tetramethylchroman-2-carboxylic acid (trolox), potassium persulphate,2,2-azobis (2-amidinopropane) dihydrochloride (AAPH), sodium fluorescein, 2,4,6-tripyridyl-s-triazine (TPTZ) and 4,4'-disulfonic acid sodium salt (ferrozine) were purchased from Sigma-Aldrich (USA). All chemicals and reagents used in the experiment were of analytical grade. The bio-assays were performed using high throughput micro-plate readers (Spectra Max Plus384, Molecular Devices, USA and Spectra Max-Gemini EM, Molecular Devices Inc., USA).

\section{Plant material collection and preparation of extracts}

Fresh plant materials, leaves of Sphaeranthus indicus L.(Asteraceae), leaves of Acronychia pedunculata L (Rutaceae), bark of Calophyllum innophyllum Linn. (Clusiaceae), bark of Symplocos cochinchinesis (Lour.) S. Moore. (Symplocaceae), bark of Tinospora cordifolia (Willd.) (Menispermaceae), bark of Flacourtia indica (Burm.f. Merr.) (Salicaceae), leaves of Leucus zeylanica L. (Lamiaceae), leaves of Barathranthus nodiflorus Thw. (Loranthaceae), leaves of Diospyros ebenum J.Koenig ex Retz (Ebenaceae) and leaves of Argyreia populifolia Choisy (Convolvulaceae) were collected from Gampaha, Sri Lanka.

Plants were identified by Ms. S. Sugathadasa and voucher specimens were deposited at Herbal Technology Section, Industrial Technology Institute, Sri Lanka (leaves of Sphaeranthus indicus L: SEL/15/11, leaves of Acronychia pedunculata L: APL/15/15, bark of Calophyllum innophyllum Linn.: CIL/15/21, bark of Symplocos cochinchinesis (Lour.) S. Moore.: SCB/15/27, bark of Tinospora cordifolia (Willd): TCB/15/32, bark of Flacourtia indica (Burm.f. Merr.): FIB/15/34, leaves of Leucus zeylanica L.: LZL/15/41, leaves of Barathranthus nodiflorus Thw.: BNL/15/44, leaves of Diospyros ebenum J.Koenig ex Retz: DEL/15/47 and leaves of Argyreia populifolia Choisy: APL/15/48) Plant materials were shade-dried under well-ventilated conditions (Relative humidity: 65-75\%), at room temperature $\left(25 \pm 2{ }^{\circ} \mathrm{C}\right)$ for $72 \mathrm{~h}$ and ground to make coarse powder using a mechanical grinder $[11,12]$. Powdered plant materials (100 g) were soaked in ethanol (500 mL) overnight and stirred for $1 \mathrm{~h}$ using a mechanical stirrer at room temperature $\left(25 \pm 2{ }^{\circ} \mathrm{C}\right)$ followed by suction filtration through a celite bed, packed in a sintered funnel. The filtrates were concentrated under reduced pressure at $40{ }^{\circ} \mathrm{C}$ using a rotary evaporator to obtain the ethanol extracts [11]. The solvent free extracts were stored in air-tight glass containers at $-20^{\circ} \mathrm{C}$ until used [13].

\section{Enzyme inhibitory activity Arachidonate 5-lipoxygenase (A5-LOX) inhibitory assay} A5-LOX inhibitory activity of plant extracts was determined by a modified spectrometric method [14]. Plant extracts were assayed within the concentration range of 10-1000 $\mu \mathrm{g} / \mathrm{mL}$. Briefly, sodium phosphate buffer (110 $\mu \mathrm{L}, 100 \mathrm{mM}, \mathrm{pH}$ 8.0), plant extracts dissolved in methanol $(10 \mu \mathrm{L})$, and A5-LOX solution $(55 \mu \mathrm{L})$ were incubated for $10 \mathrm{~min}$ at $25{ }^{\circ} \mathrm{C}$ followed by the addition of linoleic acid solution $(25 \mu \mathrm{L}, 0.08 \mathrm{mM})$. Absorbance was measured at $\lambda=234 \mathrm{~nm}$ for $10 \mathrm{~min}$ at $25{ }^{\circ} \mathrm{C}$. 
Percentage inhibition of A5-LOX was determined by comparison of reaction rates of extracts relative to control using the formula $(E-S) / E \times 100$, where $E$ and $S$ are activities of the enzyme with and without extracts, respectively. $\mathrm{IC}_{50}$ values were determined. Baicalein was used as the reference standard.

\section{Hyaluronidase inhibitory assay}

Hyaluronidase inhibitory activity of plant extracts was evaluated by a spectrometric method with modifications [15]. Extracts were assayed at the concentrations of 100 and $500 \mu \mathrm{g} / \mathrm{mL}$. Extracts $(50 \mu \mathrm{L})$ were incubated with hyaluronidase enzyme solution $(10 \mu \mathrm{L})$ at $37{ }^{\circ} \mathrm{C}$ for $10 \mathrm{~min}$ followed by the addition of calcium chloride $(12.5 \mathrm{mM}, 20 \mu \mathrm{L})$ and re-incubation at $37^{\circ} \mathrm{C}$ for $10 \mathrm{~min}$. Sodium hyaluronate $(50 \mu \mathrm{L})$ was added to the reaction mixture and incubated at $37{ }^{\circ} \mathrm{C}$ for $40 \mathrm{~min}$ followed by the addition of Sodium hydroxide $(0.9 \mathrm{M}, 10 \mu \mathrm{L})$ and Sodium borate $(0.2 \mathrm{M}, 20 \mu \mathrm{L})$ and incubation at $100{ }^{\circ} \mathrm{C}$ for $3 \mathrm{~min}$. p-Dimethylaminobenzaldehyde (PDMAB), $(50 \mu \mathrm{L}, 67 \mathrm{mM})$ was added to the reaction mixture and incubated at $37{ }^{\circ} \mathrm{C}$ for $10 \mathrm{~min}$. Absorbance was measured at $\lambda=585 \mathrm{~nm}$. Percent enzyme inhibition was calculated as given below, compared to the control. Tannic acid was used as the reference standard.

Inhibition $(\%)=[($ Abs. control - Abs. sample $) /$ Abs. control] $\times 100$.

\section{Xanthine oxidase inhibitory activity}

Xanthine oxidase inhibitory activity of plant extracts was determined by a kinetic method [16] with slight modifications. Extracts were tested at the assay concentration of $250 \mu \mathrm{g} / \mathrm{mL}$. Briefly, sodium phosphate buffer $(150 \mu \mathrm{L}$, $50 \mathrm{mM}, \mathrm{pH} 7.4)$, extracts $(10 \mu \mathrm{L})$ and xanthine oxidase solution $(10 \mu \mathrm{L})$ were incubated at $25{ }^{\circ} \mathrm{C}$ for $10 \mathrm{~min}$. The reaction was then initiated with the addition of xanthine solution $(0.1 \mathrm{mM})$. Absorbance was monitored with the change of absorbance at $\lambda=295 \mathrm{~nm}$ for $15 \mathrm{~min}$ at $25{ }^{\circ} \mathrm{C}$. Percentage inhibition of xanthine oxidase was calculated using the formula $(E-S) / E \times 100$, where $E$ is the activity of enzyme without extracts and $S$ is the activity of enzyme with extracts. Allopurinol was used as the reference standard.

\section{Nitric oxide production inhibitory activity and viability of LPS-activated RAW 264.7 macrophages}

Cell culture Murine macrophage (RAW 264.7) cell lines were purchased from ATCC, VA, USA. The RAW 264.7 cells were cultured and maintained in DMEM, supplemented with streptomycin sulfate $(100 \mu \mathrm{g} / \mathrm{mL})$, penicillin G sodium (100 units $/ \mathrm{mL})$, amphotericin B $(0.25 \mu \mathrm{g} / \mathrm{mL})$ and $10 \%$ fetal bovine serum (FBS) (Humidified atmosphere, $5 \% \mathrm{CO}_{2}, 37^{\circ} \mathrm{C}$ ). Cells were split twice a week.

Monolayer cells were plated in 96-well micro-plates at a density of $1 \times 10^{5}$ cells/well followed by the incubation (humidified atmosphere, $5 \% \mathrm{CO}_{2}, 37{ }^{\circ} \mathrm{C}$ ) for $24 \mathrm{~h}$. The plated cells were treated with extracts $(500 \mu \mathrm{g} / \mathrm{mL})$ and incubated for $30 \mathrm{~min}$ (humidified atmosphere, $5 \% \mathrm{CO}_{2}$, $37{ }^{\circ} \mathrm{C}$ ), followed by the incubation with bacterial lipopolysaccharide (LPS, $1 \mu \mathrm{g} / \mathrm{mL}$ ) for $24 \mathrm{~h}$ [17].

Nitric oxide production inhibition The inhibition of nitric oxide production was determined using the Griess assay [6]. After 24 h incubation with LPS, cell culture supernatants $(100 \mu \mathrm{L})$ were reacted with Griess reagent $(100 \mu \mathrm{L})$ and incubated for $10 \mathrm{~min}$ at room temperature and absorbance was measured at $\lambda=540 \mathrm{~nm}$. The nitrite concentration was determined using a standard curve of sodium nitrite $\left(y=0.012 x+0.036, R^{2}=0.999\right)$. Percentage inhibition of nitric oxide formation by extracts was calculated [18].

Cell viability The cytotoxicity of the extracts on RAW 264.7 cells was determined by MTT assay [19]. Cells were initially incubated (humidified atmosphere, 5\% $\left.\mathrm{CO}_{2}, 37^{\circ} \mathrm{C}\right)$ for $6 \mathrm{~h}$ and with plant extracts $(500 \mu \mathrm{g} / \mathrm{mL})$ for $30 \mathrm{~min}$. The cells were treated with LPS $(1 \mu \mathrm{g} / \mathrm{mL})$ and incubated for $24 \mathrm{~h}$. MTT solution $(20 \mu \mathrm{L}, 5 \mathrm{mg} / \mathrm{mL}$ in PBS) and FBS free DMEM $(180 \mu \mathrm{L})$ were added to the cells and incubated (humidified atmosphere with 5\% $\mathrm{CO}_{2}$ at $\left.37{ }^{\circ} \mathrm{C}\right)$ for $4 \mathrm{~h}$. DMSO $(100 \mu \mathrm{L})$ was added to dissolve the formed formazan salt and absorbance was measured at $\lambda=570 \mathrm{~nm}$. Percentage cell viability was determined [18].

Oxidative burst inhibition Oxidative burst inhibition assay was conducted at Dr. Panjwani Center for Molecular Medicine and Drug Research, International Centre for Chemical and Biological Sciences, University of Karachi, Pakistan. The institute has obtained the ethical clearance for studies on human blood from independent ethics committee, ICCBS, UoK. No: ICCBS/IEC-008-BC-2015/ Protocol/1.0.

Isolation of human polymorphoneutrophils (PMNs) Venous blood was collected from a healthy adult male volunteer (25-30 years age) to a heparinized tube and density gradient centrifugation was carried out to isolate neutrophils [20]. Briefly, whole blood (10 mL), HBSS $(10 \mathrm{~mL})$ and lympho separation medium (LSM, $10 \mathrm{~mL}$ ) were mixed and kept at room temperature for $45 \mathrm{~min}$ for serum separation. The separated serum was centrifuged at $400 \mathrm{~g}$ for $20 \mathrm{~min}$ and sedimented cells were re-centrifuged with an equal volume of LSM at $300 \mathrm{~g}$, 
$4{ }^{\circ} \mathrm{C}$ for $10 \mathrm{~min}$. The cells were re-suspended in $\mathrm{HBSS}^{-}$ and cell count was adjusted to $1 \times 10^{6}$ cells/ mL.

Chemiluminescence assay Luminol-enhanced chemiluminescence assay was performed according to a kinetic method [21] with modifications. Briefly, $25 \mu \mathrm{L}$ of diluted whole blood in $\mathrm{HBSS}^{++}$was incubated with the plant extract $(25 \mu \mathrm{L})$ at $37{ }^{\circ} \mathrm{C}$ for $15 \mathrm{~min}$ and $25 \mu \mathrm{L}$ of serum opsonized zymosan (SOZ) and $25 \mu \mathrm{L}$ of luminol were added into each well, except blank wells. The level of the ROS was recorded and inhibition of ROS production (\%) was calculated. $\mathrm{IC}_{50}$ values were determined. Ibuprofen was used as the reference standard.

\section{Antioxidant activity}

\section{2,2-diphenyl-2-picryl-hydrazyl (DPPH) free radical scavenging activity}

The DPPH free radical scavenging activity of plant extracts was determined using a spectrophotometric method with modifications [22]. Extracts were assayed within the concentration range of $10-500 \mu \mathrm{g} / \mathrm{mL}$. Extracts $(100 \mu \mathrm{L})$ were incubated with $\mathrm{DPPH}$ solution $(40 \mu \mathrm{g} / \mathrm{mL}, 200 \mu \mathrm{L})$ at room temperature $\left(25 \pm 2{ }^{\circ} \mathrm{C}\right)$ in dark for $10 \mathrm{~min}$ and absorbance was measured at $517 \mathrm{~nm}$. The DPPH free radical scavenging activity was calculated using the following equation and $\mathrm{IC}_{50}$ values were determined. Trolox was used as the reference standard.

Scavenging activity $(\%)=[($ Abs. control - Abs. sample $) /$ Abs. control] $\times 100$.

\section{Ferric reducing antioxidant power (FRAP)}

The assay was performed according to a spectrophotometric method [23] with slight modifications. Extracts were tested within the assay concentration range of 25$500 \mu \mathrm{g} / \mathrm{mL}$. Extracts $(50 \mu \mathrm{L})$ were incubated with freshly prepared FRAP reagent (Acetate buffer of $300 \mathrm{mM}$ and $\mathrm{pH}$ 3.6, TPTZ in $10 \mathrm{mM}$ in $40 \mathrm{mM} \mathrm{HCl}$, and $20 \mathrm{mM}$ ferric chloride hexahydrate solution mixed at 10:1:1, v/v/v) $(150 \mu \mathrm{L})$ at room temperature $\left(25 \pm 2{ }^{\circ} \mathrm{C}\right)$ for $8 \mathrm{~min}$. Absorbance was recorded at $\lambda=593 \mathrm{~nm}$. FRAP of extracts was expressed as mg trolox equivalents (TE)/g of extract using a standard curve of trolox $(y=0.008 x+$ $0.046, R^{2}=0.996$ ).

\section{Ferrous ion chelating (FIC) activity}

Ferrous ion chelating activity was determined according to a spectrophotometric method [24] with modifications. Plant extracts were assayed in the assay concentration range of $100-5000 \mu \mathrm{g} / \mathrm{mL}$. Extracts $(140 \mu \mathrm{L})$ were incubated with ferrous sulfate solution $(1 \mathrm{mM}, 20 \mu \mathrm{L})$ at room temperature $\left(25 \pm 2{ }^{\circ} \mathrm{C}\right)$ for $10 \mathrm{~min}$. After the incubation, ferrozine $(40 \mu \mathrm{L})$ was added to the reaction mixture and re-incubated at room temperature $\left(25 \pm 2{ }^{\circ} \mathrm{C}\right)$ for $10 \mathrm{~min}$. Absorbance was measured at $562 \mathrm{~nm}$. Percentage chelating effect was calculated with compared to control based on the following equation and $\mathrm{IC}_{50}$ values were determined. EDTA- $\mathrm{Na}_{2}$ was used as the reference standard.

Chelating activity $(\%)=[($ Abs. control - Abs. sample $) /$ Abs. control] $\times 100$.

\section{Oxygen radical absorbance capacity (ORAC)}

The oxygen radical absorbance capacity (ORAC) assay was conducted using a kinetic method [25] with modifications. Plant extracts were assayed in the assay concentration range of $1-100 \mu \mathrm{g} / \mathrm{mL}$. Extracts $(10 \mu \mathrm{L})$ were pre-incubated with phosphate buffer $(40 \mu \mathrm{L})$ and fluorescein solution $(4.8 \mu \mathrm{M}, 100 \mu \mathrm{L})$ at $37^{\circ} \mathrm{C}$ for $10 \mathrm{~min}$ and freshly prepared AAPH solution $(40 \mu \mathrm{g} / \mathrm{mL}, 50 \mu \mathrm{L})$ was added. The decay of fluorescein was monitored at $1 \mathrm{~min}$ intervals for $35 \mathrm{~min}$ at the wavelengths of $494 \mathrm{~nm}$ (excitation) and $\lambda=535 \mathrm{~nm}$ (emission). Trolox was used as the reference standard. The net area under the curve of decay of fluorescein was determined using the calibration curve of trolox $\left(y=0.035 x+0.08, R^{2}=0.999\right)$ and expressed as mg trolox equivalents (TE)/g of extract.

\section{Determination of Total polyphenolic content}

The total polyphenolic content (TPC) of plant extracts was quantified by the modified Folin-Ciocalteu method [26]. Extracts were assayed within the assay concentration range of $50-500 \mu \mathrm{g} / \mathrm{mL}$. Plant extracts $(110 \mu \mathrm{L})$ were incubated with folin-ciocalteu reagent and sodium carbonate solution $(10 \% w / v, 70 \mu \mathrm{L})$ for $30 \mathrm{~min}$ at room temperature $\left(25 \pm 2{ }^{\circ} \mathrm{C}\right)$. Absorbance was recorded at $765 \mathrm{~nm}$. TPC was calculated using the calibration curve of Gallic acid standard curve $\left(y=0.053 x+0.105, R^{2}=\right.$ 0.993) and expressed as $\mathrm{mg}$ gallic acid equivalents (GAE)/g of extract.

\section{Determination of Total flavonoid content}

The total flavonoid content (TFC) of plant extracts was quantified by the aluminium chloride method [27]. Extracts were tested within the assay concentration range of $50-500 \mu \mathrm{g} / \mathrm{mL}$. Extracts $(100 \mu \mathrm{L})$ were incubated with $\mathrm{AlCl}_{3}$-methanol solution $(2 \%, 100 \mu \mathrm{L})$ for $10 \mathrm{~min}$ at room temperature $\left(25 \pm 2{ }^{\circ} \mathrm{C}\right)$ and absorbance was recorded at $415 \mathrm{~nm}$. TFC was calculated using a calibration curve of quercetin $\left(y=0.033 \times-0.002, R^{2}=\right.$ $0.999)$ and expressed in terms of $\mathrm{mg}$ quercetin equivalents $(\mathrm{QE}) / \mathrm{g}$ of extract.

Gas chromatography - mass spectroscopy (GC-MS) analysis The total ethanol extract of bark of $F$. indica was analysed by GC-MS using Thermoscientific Trace 1300 GC system, coupled with ISQ QD mass detector (EI mode, 
mass range of $\mathrm{m} / \mathrm{z} 40-450)$. The GC system is equipped with a programmable temperature vaporization (PTV) inlet and a Supelcowax capillary column $(30 \mathrm{~m} \times$ $0.25 \mathrm{~mm} \times 0.25 \mu \mathrm{m}$ ), fused with silica and polyethylene glycol as the stationary phase.

Sample was dissolved in ethanol $(0.60 \mathrm{~g} / \mathrm{mL})$ and $500 \mu \mathrm{L}$ of head space gas was introduced to the PTV inlet. The injector temperature was set at $250{ }^{\circ} \mathrm{C}$ with an initial oven temperature of $60{ }^{\circ} \mathrm{C}$, which was set to increase at a rate of $5{ }^{\circ} \mathrm{C} \mathrm{min}^{-1}$ to reach up to $220^{\circ} \mathrm{C}$. Helium was used as the carrier gas (Flow rate: $1 \mathrm{~mL} \mathrm{~min}^{-1}$ ). The compounds in the extract were matched and identified using mass spectral database of NIST 11, USA.

\section{Analysis of phenolic compounds using high Performanace liquid chromatography (HPLC)}

The ethanol extract of $F$. indica was dissolved in methanol $(5 \mathrm{mg} / \mathrm{mL})$ and filtered through a membrane filter $(0.25 \mu \mathrm{m})$ for HPLC analysis. The HPLC system was equipped with a Agilent 1260 Infinity II system, consisting of a quaternary pump (G7111A), vial sampler, coloumn heater and Diode array detector (WR G7115A). Separation was achieved on a reversed phase coloumn C $18(250 \mathrm{~mm} \times 4.6 \mathrm{~mm} \times 5 \mu \mathrm{m})$. The eluates were detected at 254, 280 and $320 \mathrm{~nm}$. Two solvent mixtures were used as the mobile phase in a gradient system. Water/formic acid (1000/0.005 v/v) was used as solvent $\mathrm{A}$ and methanol was used as solvent B. The total flow rate was $0.5 \mathrm{~mL} / \mathrm{min}$. The gradient profile of the mobile phase was from $10 \%$ B linearly to $70 \%$ B in $60 \mathrm{~min}$ followed by an isocratic flow for $10 \mathrm{~min}$ and back to $10 \% \mathrm{~B}$ at $90 \mathrm{~min}$ followed by isocratic flow for $10 \mathrm{~min}$ to re-equilibrate [28].

\section{Statistical analysis}

All analysis was carried out in triplicate and experimental results were expressed as mean \pm standard error (SE), analysed with one-way ANOVA. Turkey's multiple range tests was applied for mean separation, when ANOVA was significant $(p<0.05) . \mathrm{IC}_{50}$ values were calculated using linear regression analysis. Pearson's correlation coefficient was used for the correlation analysis $(p<0.05)$ (IBM SPSS Statistics 22.0).

\section{Results}

Enzyme inhibitory activities of selected medicinal plants Arachidonate 5-lipoxygenase inhibitory activity

Based on the percent inhibition in the screening, the results revealed that, the ethanol bark extract of $F$. indica had the highest A5-LOX inhibitory activity followed by the extracts of S. cochinchinesis and C. innophyllum, while the extract of $T$. cordifolia had the lowest activity (Table 2). Apart from the extracts of $A$. pedunculata, $L$. zeylanica and $B$. nodiflorus, the other extracts showed
Table 2 Anti-A5-LOX activity of ethanol extracts of medicinal plants

\begin{tabular}{lll}
\hline Plant name & A5-LOX Inhibiton (\%) & $\begin{array}{l}\text { Anti-A5-LOX activity } \\
I_{50}\left(\mu \mathrm{g} \mathrm{mL^{-1 }}\right)\end{array}$ \\
\hline Sphaeranthus indicus & $32.45 \pm 0.45^{\mathrm{a}}$ & $136.69 \pm 1.79^{\mathrm{a}}$ \\
Acronychiapedunculata & $17.45 \pm 0.94^{\mathrm{b}}$ & $294.68 \pm 2.23^{\mathrm{b}}$ \\
Calophyllum innophyllum & $67.14 \pm 0.51^{\mathrm{c}}$ & $74.82 \pm 1.35^{\mathrm{c}}$ \\
Symplocos cochinchinesis & $70.12 \pm 0.36^{\mathrm{c}}$ & $39.01 \pm 0.91^{\mathrm{d}}$ \\
Tinospora cordifolia & $12.71 \pm 0.71^{\mathrm{b}}$ & $393.63 \pm 1.74^{\mathrm{e}}$ \\
Flacourtia indica & $89.35 \pm 1.24^{\mathrm{d}}$ & $22.75 \pm 1.94^{\mathrm{f}}$ \\
Leucus zeylanica & $19.37 \pm 0.11^{\mathrm{b}}$ & $258.03 \pm 1.91^{\mathrm{g}}$ \\
Barathranthus nodiflorus & $9.38 \pm 0.32^{\mathrm{e}}$ & $213.27 \pm 1.55^{\mathrm{h}}$ \\
Diospyros ebenum & $34.91 \pm 0.84^{\mathrm{a}}$ & $143.76 \pm 1.03^{\mathrm{a}}$ \\
Argyreia populifolia & $32.89 \pm 0.17^{\mathrm{a}}$ & $152.41 \pm 1.00^{\mathrm{i}}$ \\
Baicalein & $97.64 \pm 0.65^{\mathrm{f}}$ & $1.76 \pm 0.15^{\mathrm{j}}$ \\
\hline
\end{tabular}

Data represented as mean \pm SE $(N=3) .{ }^{*}$ A5-LOX Inhibition at $100 \mu \mathrm{g} / \mathrm{mL}$. Mean within each column followed by the same letter are not significantly different at $p<0.05$

high to moderate A5-LOX inhibitory activities. Based on the $\mathrm{IC}_{50}$ values, the extract of $F$. indica (Fig. 1) showed the highest A5-LOX inhibitory activity followed by $S$. cochinchinesis and C. innophyllum in a dose dependent manner confirming the results of the initial screening (Table 2). The activities of the extracts were found to be significantly different from the positive control baicalein, which showed a strong dose dependent activity against A5-LOX enzyme activity.

\section{Hyaluronidase inhibitory activity}

The hyaluronidase inhibitory activities ranged from $16.27 \pm 1.00$ to $42.31 \pm 2.00 \%$ for the tested plant extracts. The ethanol bark extracts of B. nodiflorus and $D$. ebenum showed the highest activities followed by the extracts of $A$. pedunculata and $F$. indica (Table 3 ). The extracts of $S$. indicus, C. innophyllum and T. cordifolia showed no inhibitory activities against hyaluronidase

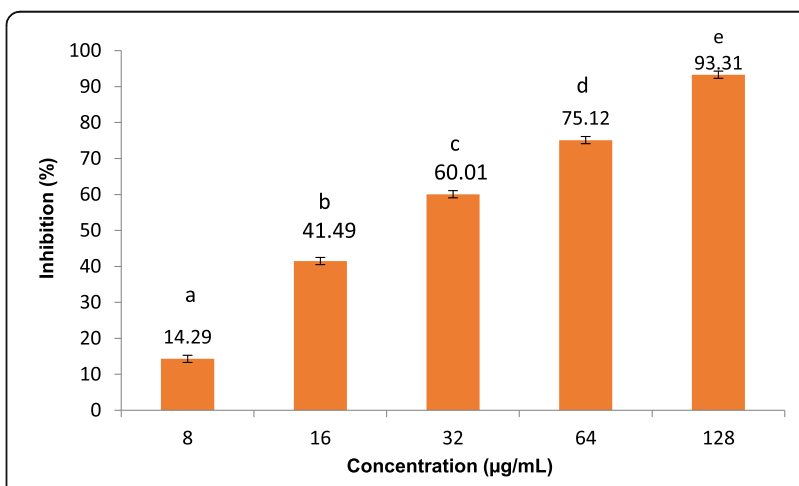

Fig. 1 A5-LOX inhibitory activities of ethanol extract of bark of Flacourtia indica. Results are presented as mean $\pm \mathrm{SE}(N=3)$. Means followed by the same letter are not significantly different at $p<0.05$ 
Table 3 Xanthine oxidase and hyaluronidase enzyme inhibitory activities of total ethanol extracts of medicinal plants

\begin{tabular}{lll}
\hline Plant Name & $\begin{array}{l}\text { Xanthine oxidase } \\
\text { inhibition }\end{array}$ & $\begin{array}{l}\text { Hyaluronidase } \\
\text { inhibition }\end{array}$ \\
\hline $\begin{array}{l}\text { Sphaeranthus indicus } \\
\text { Acronychia }\end{array}$ & $\begin{array}{l}\text { 30.35 } \pm 0.32^{\mathrm{a}, \mathrm{f}} \\
\text { pedunculata }\end{array}$ & $\mathrm{NI}$ \\
$\begin{array}{l}\text { Calophyllum } \\
\text { innophyllum }\end{array}$ & $38.96 \pm 0.14^{\mathrm{b}, \mathrm{d}}$ & $36.60 \pm 1.02^{\mathrm{a}}$ \\
$\begin{array}{l}\text { Symplocos } \\
\text { cochinchinesis }\end{array}$ & $44.86 \pm 1.43^{\mathrm{c}}$ & $\mathrm{NI}$ \\
$\begin{array}{l}\text { Tinospora cordifolia } \\
\text { Flacourtia indica }\end{array}$ & $17.92 \pm 1.73^{\mathrm{d}}$ & $\mathrm{Nl} .49 \pm 1.09^{\mathrm{b}}$ \\
Leucus zeylanica & $13.26 \pm 0.26 \pm 0.18^{\mathrm{e}}$ & $36.67 \pm 2.23^{\mathrm{a}}$ \\
$\begin{array}{l}\text { Barathranthus } \\
\text { nodiflorus }\end{array}$ & $6.26 \pm 0.93^{\mathrm{b}}$ & $24.38 \pm 2.09^{\mathrm{b}}$ \\
Diospyros ebenum & $24.76 \pm 2.16^{\mathrm{a}}$ & $42.31 \pm 2.00^{\mathrm{d}}$ \\
Argyreia populifolia & $32.79 \pm 2.16^{\mathrm{f}}$ & $41.60 \pm 1.18^{\mathrm{d}}$ \\
Allopurinol & $99.26 \pm 0.72^{\mathrm{g}}$ & $16.27 \pm 1.00^{\mathrm{e}}$ \\
Tannic acid & $\mathrm{NA}$ & $\mathrm{NA}$ \\
\hline
\end{tabular}

Inhibition (\%) of xanthine oxidase and hyaluronidase is recorded at 250 and $500 \mu \mathrm{g} / \mathrm{mL}$ assay concentrations respectively

Data represented as mean $\pm \mathrm{SE}(N=3)$. Means followed by the same letter are not significantly different at $p<0.05$, NA Not applicable

enzyme (Table 3). The extracts of $B$. nodiflorus and $D$. ebenum showed moderate activities (Table 3) compared to the reference standard tannic acid and good, comparable activities when compared with the reported activity of indomethacine $(50 \%, 500 \mu \mathrm{g} / \mathrm{mL})$ [28] a clinical drug in use against inflammation.

\section{Xanthine oxidase inhibitory activity}

All extracts showed some inhibitory activity against xanthine oxidase enzyme and activities ranged from $6.26 \pm 0.93$ to $70.74 \pm 0.95 \%$. The results revealed that, the ethanol bark extract of $F$. indica had the highest inhibitory activity followed by the extracts of $S$. cochinchinesis and C. innophyllum (Table 3). The extracts of A. pedunculata and $A$. populifolia showed significantly low inhibitory activities against xanthine oxidase enzyme with respect to the reference standard allopurinol (Table 3). The extract of $F$. indica, which showed the highest xanthine oxidase inhibitory activity showed significant $(p<0.05)$, dose dependent inhibitions within the concentration range of $31.25-500 \mu \mathrm{g} / \mathrm{mL}$ with a $\mathrm{IC}_{50}$ value of $176.62 \pm 0.7 \mu \mathrm{g} / \mathrm{mL}$ (Fig. 2; Allopurinol: $\mathrm{IC}_{50}: 2.33 \pm 0.51 \mu \mathrm{g} / \mathrm{mL}$ ).

\section{Nitric oxide production inhibitory activity and viability of LPS-activated RAW 264.7 macrophages}

The inhibitory activities of extracts were moderate to low in comparison to the reference standard L-NMMA and ranged from $3.63 \pm 0.69 \%$ to $38.07 \pm 0.93 \%$. Of the tested plant extracts, the extracts of $F$. indica, $S$.

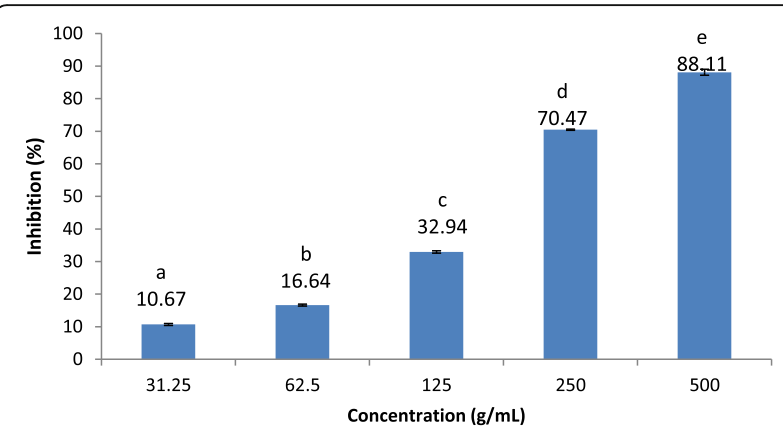

Fig. 2 Xanthine oxidase inhibitory activities of ethanol extract of bark of Flacourtia indica. Results are presented as mean $\pm \mathrm{SE}(N=3)$. Means followed by the same letter are not significantly different at $p<0.05$

cochinchinesis and C. innophyllum showed significantly high activities, while that of $S$. indicus, $T$. cordifolia, $L$. zeylanica and $B$. nodiflorus showed significantly low activities (Table 4). The extracts showed no cytotoxicity (Cell viability: $>80 \%$ ) at the tested concentration (Table 4 ).

\section{Oxidative burst inhibition}

The ethanol bark extract of $F$ indica, which was identified as a highly anti-inflammatory extract was assessed for the effect on oxidative burst response on human whole blood and isolated PMNs. The extract showed a significant inhibition of ROS production on human whole blood $\left(\mathrm{IC}_{50}: 47.64 \pm 2.32 \mu \mathrm{g} / \mathrm{mL}\right)$, which was found to be dose-dependent (12.5-200 $\mu \mathrm{g} / \mathrm{mL}$ ) (Fig. 3a). Interestingly, the extract showed promising, significant oxidative burst inhibitory effect when tested on isolated PMNs $\left(\mathrm{IC}_{50}: 5.02 \pm 0.38 \mu \mathrm{g} / \mathrm{mL}\right.$ ) (Fig. 3b), which is comparable with the reference drug Ibuprofen $\left(\mathrm{IC}_{50}: 5.12 \pm\right.$ $0.45 \mu \mathrm{g} / \mathrm{mL})$.

\section{Anti-oxidant activity}

Anti-oxidant capacities of the extracts were evaluated using four different methods including the DPPH free radical scavenging, FIC, FRAP and ORAC assays. The extracts showed high to low DPPH free radical scavenging activities, having the $\mathrm{IC}_{50}$ values within the range of $6.99 \pm 0.02-743.49 \pm 1.94 \mu \mathrm{g} / \mathrm{mL}$. The highest $\mathrm{DPPH}$ free radical scavenging activities were showed by the extracts of C. innophyllum and S. cochinchinesis followed by the extracts of $F$. indica and $S$. indicus in comparison to the reference standard trolox (Table 5).

In FIC assay, the extracts showed low chelating activities, indicating high $\mathrm{IC}_{50}$ values in comparison to the reference standard EDTA- $\mathrm{Na}_{2}$. The extracts of $T$. cordifolia, D. ebenum and A. populifolia showed no chelating activity within the tested assay concentration range of $100-5000 \mu \mathrm{g} / \mathrm{mL}$. Dose dependent activities were showed by the extracts of $A$. pedunculata and $S$. 
Table 4 Inhibitory activities of ethanol extracts of medicinal plants on nitric oxide production and viability of LPS-activated RAW264.7 macrophages

\begin{tabular}{llll}
\hline Plant name & Nitric oxide production $(\mu \mathrm{M})$ & \% NO inhibition & \% Cell viability \\
\hline Sphaeranthus indicus & $31.11 \pm 0.17$ & $9.46 \pm 0.21^{\mathrm{a}, \mathrm{b}}$ & $87.21 \pm 0.50$ \\
Acronychia pedunculata & $30.39 \pm 0.07$ & $11.56 \pm 0.21^{\mathrm{b}}$ & $89.76 \pm 0.35$ \\
Calophyllum innophyllum & $23.67 \pm 0.27$ & $31.12 \pm 0.78^{\mathrm{c}}$ & $88.89 \pm 0.82$ \\
Symplocos cochinchinesis & $22.50 \pm 0.28$ & $34.52 \pm 0.78^{\mathrm{c}}$ & $82.15 \pm 0.31$ \\
Tinospora cordifolia & $32.89 \pm 0.24$ & $2.40 \pm 0.69^{\mathrm{a}}$ & $94.56 \pm 2.57$ \\
Flacourtia indica & $21.28 \pm 0.32$ & $38.07 \pm 0.93^{\mathrm{c}}$ & $87.31 \pm 0.50$ \\
Leucus zeylanica & $33.11 \pm 0.24$ & $3.63 \pm 0.69^{\mathrm{a}}$ & $93.02 \pm 0.67$ \\
Barathranthus nodiflorus & $31.22 \pm 0.25$ & $9.13 \pm 0.72^{\mathrm{a}, \mathrm{b}}$ & $87.11 \pm 1.16$ \\
Diospyros ebenum & $29.08 \pm 0.29$ & $15.36 \pm 0.85^{\mathrm{d}}$ & $85.43 \pm 1.22$ \\
Argyreia populifolia & $27.64 \pm 0.15$ & $19.56 \pm 0.43^{\mathrm{d}}$ & $87.10 \pm 0.56^{\mathrm{e}}$ \\
L-NMMA & $0.97 \pm 0.12$ & $97.10 \pm 0.61$ \\
\hline
\end{tabular}

Data represented as mean $\pm \mathrm{SE}(N=3)$. Mean within each column followed by the same letter are not significantly different at $p<0.05$. *Inhibition $(\%)$ at the assay concentration of $500 \mu \mathrm{g} / \mathrm{mL}$
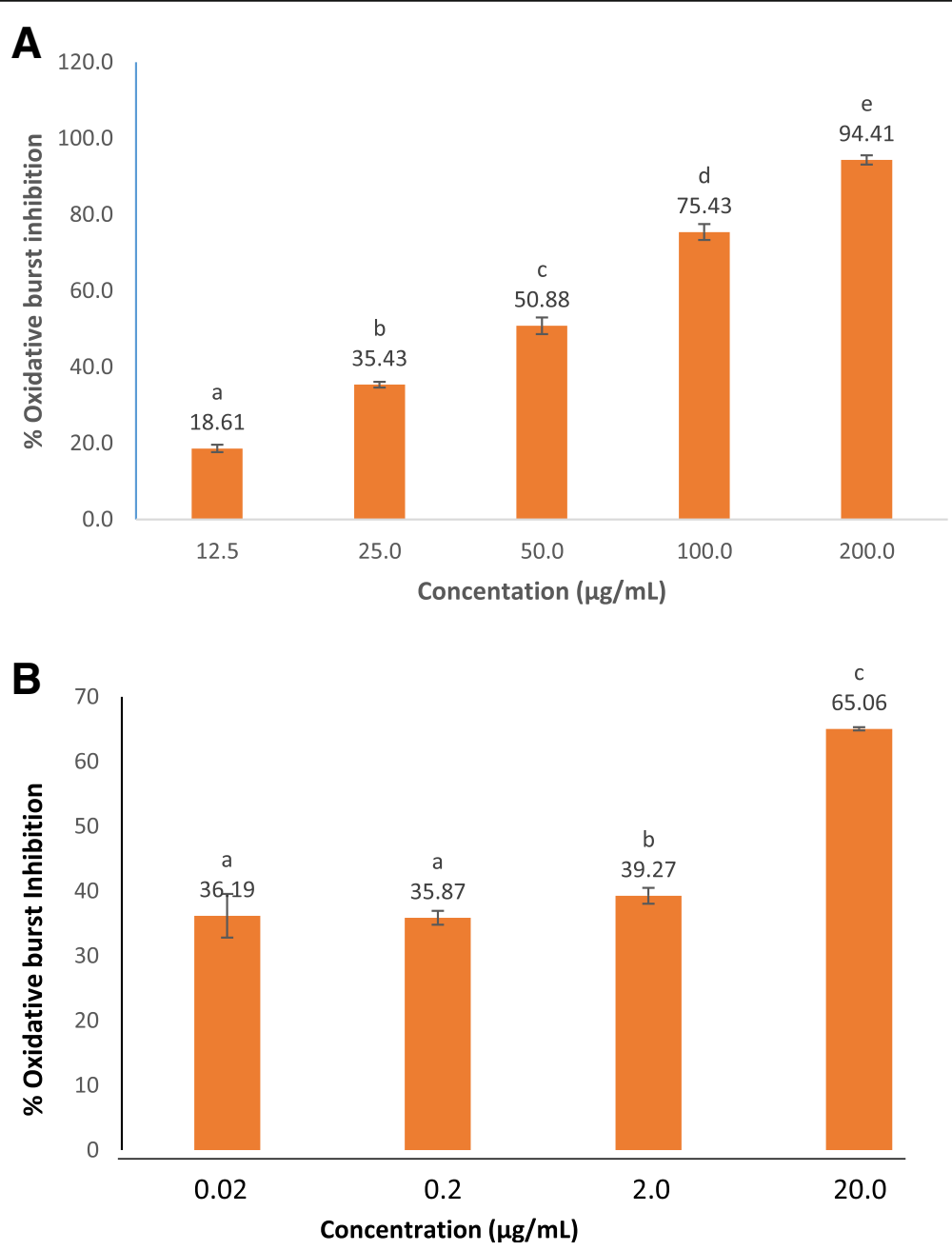

Fig. 3 Oxidative burst inhibitory activities of ethanol extract of bark of Flacourtia indica on human whole blood (a) and polymorphoneutrophils (b). Results are presented as mean $\pm \mathrm{SE}(\mathrm{N}=3)$. Means followed by the same letter are not significantly different at $p<0.05$ 
Table 5 Antioxidant activities of ethanol extracts of medicinal plants

\begin{tabular}{|c|c|c|c|c|}
\hline \multirow[t]{2}{*}{ Plant Name/Standard } & \multicolumn{2}{|c|}{$\mathrm{IC}_{50}\left(\mu \mathrm{gmL} \mathrm{L}^{-1}\right) /$ Inhibition $(\%)^{*}$} & \multirow{2}{*}{$\begin{array}{l}\text { FRAP values } \\
\text { (mg TE/g) }\end{array}$} & \multirow{2}{*}{$\begin{array}{l}\text { ORAC values } \\
\text { (mg TE/g) }\end{array}$} \\
\hline & $\mathrm{DPPH}$ & $\mathrm{FIC}$ & & \\
\hline Sphaeranthusindicus & $109.33 \pm 1.19^{a}$ & $19.21 \pm 0.56^{*}$ & $326.15 \pm 3.53^{\mathrm{a}}$ & $1018.71 \pm 9.96^{\mathrm{a}}$ \\
\hline Acronychiapedunculata & $743.49 \pm 1.94^{b}$ & $974.56 \pm 2.31^{\mathrm{a}}$ & $741.64 \pm 1.75^{b}$ & $322.67 \pm 1.94^{b}$ \\
\hline Calophyllum nnophyllum & $6.99 \pm 0.02^{c}$ & $19.50 \pm 0.71^{*}$ & $2613.00 \pm 7.23^{c}$ & $2111.0 \pm 6.35^{c}$ \\
\hline Symplocos cochinchinesis & $9.85 \pm 0.28^{c}$ & $1093.53 \pm 4.04^{b}$ & $2181.61 \pm 2.16^{d}$ & $2910.7 \pm 12.9^{d}$ \\
\hline Tinospora cordifolia & $389.20 \pm 0.75^{d}$ & $\mathrm{NI}$ & $586.66 \pm 3.29^{e}$ & $121.29 \pm 2.12^{\mathrm{e}}$ \\
\hline Flacourtia indica & $26.37 \pm 0.49^{e}$ & $8.29 \pm 0.26^{*}$ & $375.20 \pm 2.79^{f}$ & $1480.20 \pm 11.5^{f}$ \\
\hline Leucus zeylanica & $352.65 \pm 2.12^{f}$ & $33.46 \pm 0.66^{*}$ & $157.69 \pm 1.85^{9}$ & $63.69 \pm 1.16^{9}$ \\
\hline Barathranthus nodiflorus & $282.22 \pm 1.78^{9}$ & $33.37 \pm 0.40 *$ & $427.29 \pm 2.07^{h}$ & $18.07 \pm 0.42^{h}$ \\
\hline Diospyros ebenum & $177.32 \pm 1.03^{h}$ & $\mathrm{NI}$ & $369.18 \pm 0.61^{f}$ & $95.24 \pm 0.00^{e, g}$ \\
\hline Argyreia populifolia & $288.81 \pm 1.45^{9}$ & $\mathrm{Nl}$ & $268.01 \pm 1.53^{i}$ & $479.55 \pm 1.80^{i}$ \\
\hline Trolox & $5.29 \pm 0.09^{c}$ & NA & NA & NA \\
\hline EDTA-Na 2 & NA & $13.07 \pm 0.64^{c}$ & NA & NA \\
\hline GreenTea & NA & NA & NA & $1662.82 \pm 0.22^{j}$ \\
\hline
\end{tabular}

Data represented as mean \pm SE $(N=3)$. Mean within each column followed by the same letter are not significantly different at $p<0.05$. *Inhibition (\%) at the assay concentration of $1000 \mu \mathrm{g} / \mathrm{mL}$, NA Not applicable

cochinchinesis. For the remaining extracts, which showed chelating activity, dose response studies were not carried out due to the interference of turbidity of the reaction mixture at higher concentrations $(>1000 \mu \mathrm{g} / \mathrm{mL})$ (Table 5).

In FRAP assay, the extracts showed low to high reducing power within the range of $157.69 \pm 1.85-2613.00 \pm$ $7.23 \mathrm{mg} \mathrm{TE} / \mathrm{g}$. The extract of C. innophyllum showed the highest FRAP value followed by the extracts of $S$. cochinchinesis and A. pedunculata. The extract of L. zeylanica showed the lowest FRAP (Table 5).

The ORAC of extracts ranged from $18.07 \pm 0.42-$ $2910.7 \pm 12.9 \mathrm{mg} \mathrm{TE} / \mathrm{g}$. The extract of $S$. cochinchinesis showed the highest among the extracts and even significantly higher ORAC in comparison to the standard green tea extract. The extracts of C. innophyllum, $F$. indica and $S$. indicus also showed high ORAC values and that of L. zeylanica showed the lowest ORAC, compared to other extracts (Table 5).

\section{Total polyphenol and flavonoid contents}

The total polyphenol contents of the extracts ranged from $10.63 \pm 0.22-661.42 \pm 2.67 \mathrm{mg}$ GAE/g. The extract of $S$. cochinchinesis showed the significantly highest polyphenol content followed by that of $C$. innoplyllum and $A$. pedunculata. The extracts of $L$. zeylanicus and D. ebenum showed the lowest polyphenolic contents (Fig. 4).

The flavonoid contents of the extracts ranged from $3.69 \pm 0.15-72.74 \pm 0.76 \mathrm{mg} \mathrm{QE} / \mathrm{g}$. The extract of $S$. cochinchinesis showed the highest flavonoid content and that of $S$. indicus and $F$. indica showed the lowest flavonoid contents. The extracts of B. nodiflorus (32.94 $\pm 0.88 \mathrm{mg} \mathrm{QE} / \mathrm{g})$ and D. ebenum $(30.68 \pm 0.30 \mathrm{mg} \mathrm{QE} / \mathrm{g})$ also showed significant flavonoid contents (Fig. 4).

\section{Correlation between assays}

The correlation analysis is important to get an understanding of statistical relationships between different assays. The $p$ values resulted from the correlation analysis among ten assays are given in Table 6 .

Gas chromatography - mass spectroscopy (GC-MS) analysis of ethanol extract of bark of Flacoutia indica

The GC-MS analysis of ethanol extract of bark of $F$. indica revealed the presence of six phytoconstituents including acid esters and fatty acid derrivatives (Table 7). Propan-2-yl tetradecanoate, [1,1'-Bicyclopropyl]-2-octanoic acid, 2'-hexyl-, methyl ester, Linoleic acid ethyl ester, Hexadecanoic acid, ethyl ester and Benzoic acid, ethyl ester were identified as major compounds (> $2 \%$ peak area) (Fig. 5).

\section{Analysis of phenolic compounds using high performance liquid chromatography (HPLC)}

The HPLC analysis produced a well resolved chromatogram representing peaks corresponding to retention time of phenolic compounds. The HPLC chromatogram of ethanol bark extract of F. indica at 254, 280 and $320 \mathrm{~nm}$ is given in Fig. 6.

\section{Discussion}

Enzyme inhibitory activities of selected medicinal plants Arachidonate 5-lipoxygenase inhibitory activity

In this assay, all the extracts showed significant $(p<0.05)$ A5-LOX inhibitory activities at the tested concentrations. 

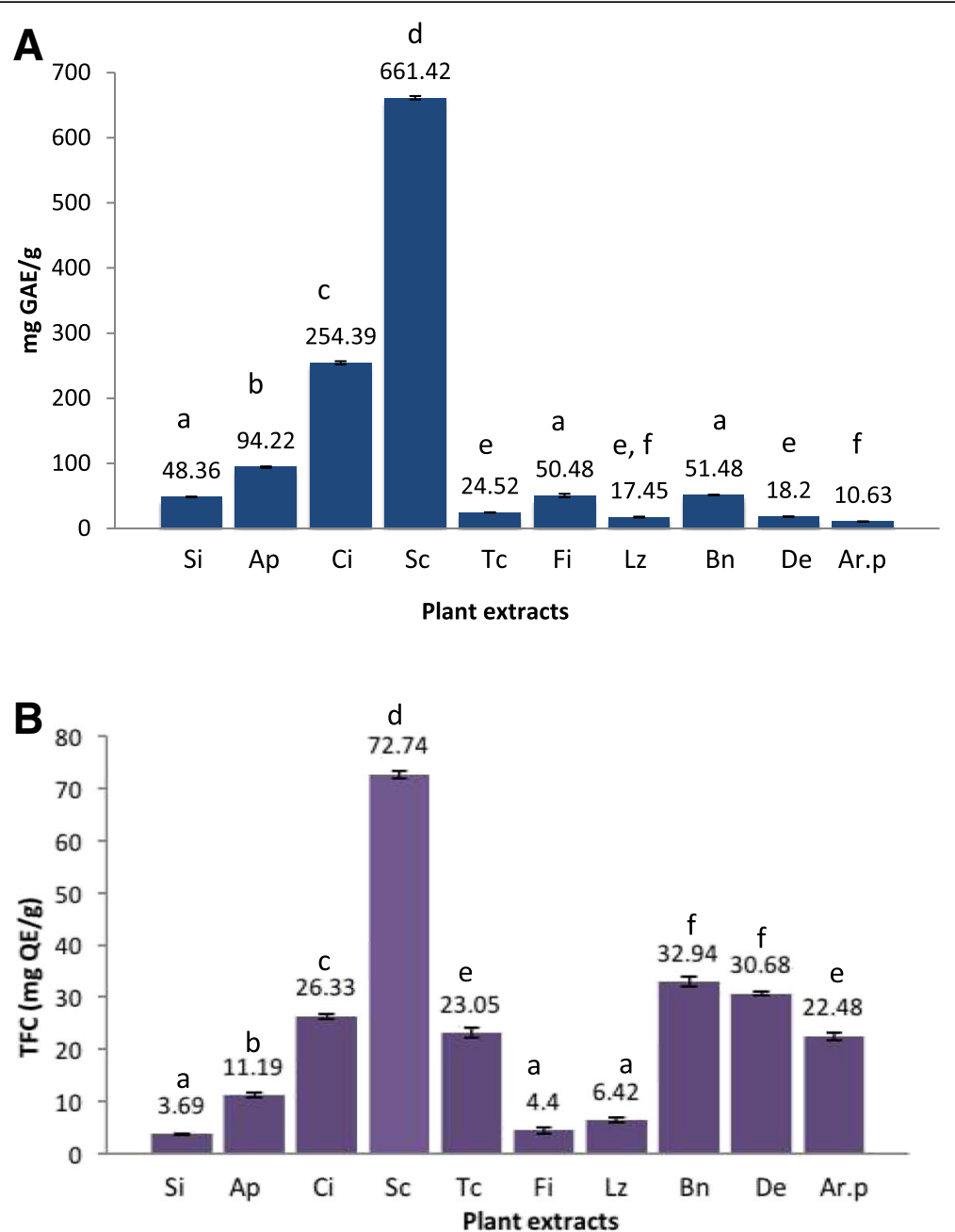

Fig. 4 Total polyphenolic contents (a) and total flavonoid Contents (b) of plant extracts. Results are presented as mean $\pm S E(N=3)$. Means followed by the same letter are not significantly different at $p<0.05$. Si:Sphaeranthus indicus, Ap:Acronychia pedunculata, Ci: Calophyllum innophyllum, Sc: Symplocos cochinchinesis, Tc:Tinospora cordifolia, Fi: Flacourtia indica, Lz: Leucus zeylanica, Bn:Barathranthus nodiflorus, De: Diospyros ebenum, Ar.p: Argyria populiflia.

Table 6 Pearson's correlation coefficients of in-vitro anti-inflammatory activities, antioxidant activities, total phenolic and total flavonoids content of extracts

\begin{tabular}{|c|c|c|c|c|c|c|c|c|c|c|}
\hline & LOX & $\mathrm{HYL}$ & $x O$ & $\mathrm{NO}$ & DPPH & FRAP & $\mathrm{FIC}$ & ORAC & TPC & TFC \\
\hline A5-LOX & 1 & $0.327^{\text {ns }}$ & $0.930^{* *}$ & $0.950^{* *}$ & $-0.736^{* *}$ & $.545^{* *}$ & $.150^{\text {ns }}$ & $.844^{* *}$ & $.540^{* *}$ & $0.228^{\text {ns }}$ \\
\hline HYL & & 1 & $0.326^{\mathrm{ns}}$ & $0.371^{*}$ & $-0.022^{\mathrm{ns}}$ & $-.297^{\text {ns }}$ & $.115^{\mathrm{ns}}$ & $-.043^{\mathrm{ns}}$ & $-.081^{\text {ns }}$ & $-0.059^{\text {ns }}$ \\
\hline XO & & & 1 & $0.864^{* *}$ & $-.728^{* *}$ & $.287^{\mathrm{ns}}$ & $-.041^{\mathrm{ns}}$ & $.696^{* *}$ & $.326^{\mathrm{ns}}$ & $0.069^{\text {ns }}$ \\
\hline NO & & & & 1 & $-.656^{* *}$ & $.592^{* *}$ & $.243^{\mathrm{ns}}$ & $.829^{* *}$ & $.587^{* *}$ & $0.368^{*}$ \\
\hline DPPH & & & & & 1 & $-.417^{*}$ & $.270^{\mathrm{ns}}$ & $-.675^{* *}$ & $-.416^{*}$ & $-0.324^{\mathrm{ns}}$ \\
\hline FRAP & & & & & & 1 & $.429^{*}$ & $.811^{* *}$ & $.810^{* *}$ & $0.607^{* *}$ \\
\hline FIC & & & & & & & 1 & $.436^{*}$ & $.707^{* *}$ & $0.520^{* *}$ \\
\hline ORAC & & & & & & & & 1 & $.857^{* *}$ & $0.523^{* *}$ \\
\hline TPC & & & & & & & & & 1 & $0.821^{* *}$ \\
\hline TFC & & & & & & & & & . & 1 \\
\hline
\end{tabular}

The statistical significance is represented with ${ }^{* *} p<0.01$ and ${ }^{*} p<0.05 . n$ s non-significant 
Table 7 GC-MS data of ethanol bark extract of Flacutia indica

\begin{tabular}{llll}
\hline Retention time & Name of the compound & Molecular formula & Peak area \% \\
\hline 16.39 & Benzoic acid, ethyl ester & $\mathrm{C}_{9} \mathrm{H}_{10} \mathrm{O}_{2}$ & 2.42 \\
24.07 & Propan-2-yl tetradecanoate & $\mathrm{C}_{17} \mathrm{H}_{34} \mathrm{O}_{2}$ & 16.27 \\
27.87 & Estra-1,3,5(10)-trien-17á-ol & $\mathrm{C}_{18} \mathrm{H}_{24} \mathrm{O}$ & 0.94 \\
28.14 & Hexadecanoic acid, ethyl ester & $\mathrm{C}_{18} \mathrm{H}_{36} \mathrm{O}_{2}$ & 8.29 \\
32.83 & Linoleic acid ethyl ester & $\mathrm{C}_{20} \mathrm{H}_{36} \mathrm{O}_{2}$ & 7.72 \\
38.17 & {$\left[1,1^{\prime}\right.$-Bicyclopropyl]-2-octanoic acid, 2'-hexyl-, methyl ester } & $\mathrm{C}_{21} \mathrm{H}_{38} \mathrm{O}_{2}$ & 12.56 \\
\hline
\end{tabular}

The ethanol bark extract of $F$. indica showed the highest A5-LOX inhibitory activity followed by that of S. cochinchinesis over the other extracts. When compared with the reported A5-LOX inhibitory activity of Caffeic acid, ( $\mathrm{IC}_{50}$ : $57.0 \mu \mathrm{g} / \mathrm{mL}$ ), [29] which is a known lipoxygenase inhibitor, the $\mathrm{IC}_{50}$ values of bark extracts of $F$. indica and $S$. cochinchinesis are about 2.5 fold and 1.5 fold lower than that of caffeic acid, respectively so that could be considered as even more potent than caffeic acid as A5-LOX inhibitors. To best of our knowledge, no previous studies have been conducted on A5-LOX inhibitory potential of extracts of F. indica and S. cochinchinesis.

\section{Hyaluronidase inhibitory activity}

In the hyaluronidase inhibitory assay, the extracts showed moderate to low anti-hyaluronidase activities at the tested concentration in comparison to the reference standard tannic acid. The extracts of $B$. nodiflorus and $D$. ebenum exhibited the highest anti-hyaluronidase activities compared to the other extracts. B. nodiflorus and $D$. ebenum are two medicinal plants endemic to Sri Lanka, that have been less exploited in the field of scientific research. The hyaluronidase inhibitory properties of these two plant extracts are recorded for the first time to upgrade the medicinal value of the species.

\section{Xanthine oxidase inhibitory activity}

All the extracts studied showed significant xanthine oxidase inhibitory activity $(\mathrm{p}<0.05)$. The extract of $F$. indica showed the highest, xanthine oxidase inhibitory activity compared to the other extracts tested. This promising anti-xanthine oxidase potential of the extract of $F$. indica may be further supported by the traditional use of extracts of F. indica in the treatment of gouty arthritis. Specifically bark extracts have been used in the treatment of gout in the Unani system of medicine, where xanthine oxidase enzyme plays a major role in pathogenesis by imparting inflammation and catalyzing the formation of uric acid crystals leading to arthritic conditions [30].

\section{Nitric oxide production inhibitory activity and viability of LPS-activated RAW 264.7 macrophages}

Of the studied extracts, $F$. indica bark showed the highest NO production inhibitory activity. The NO production inhibitory activity could be either because of the direct inhibition of iNOs enzyme catalytic activity or expression of nitric oxide synthase. The high cell viability observed in the MTT cytotoxicity assay is evident for the non-toxic nature of the tested extracts confirming, that the observed $\mathrm{NO}$ production inhibitions are not due to any cytotoxic effect of extracts.

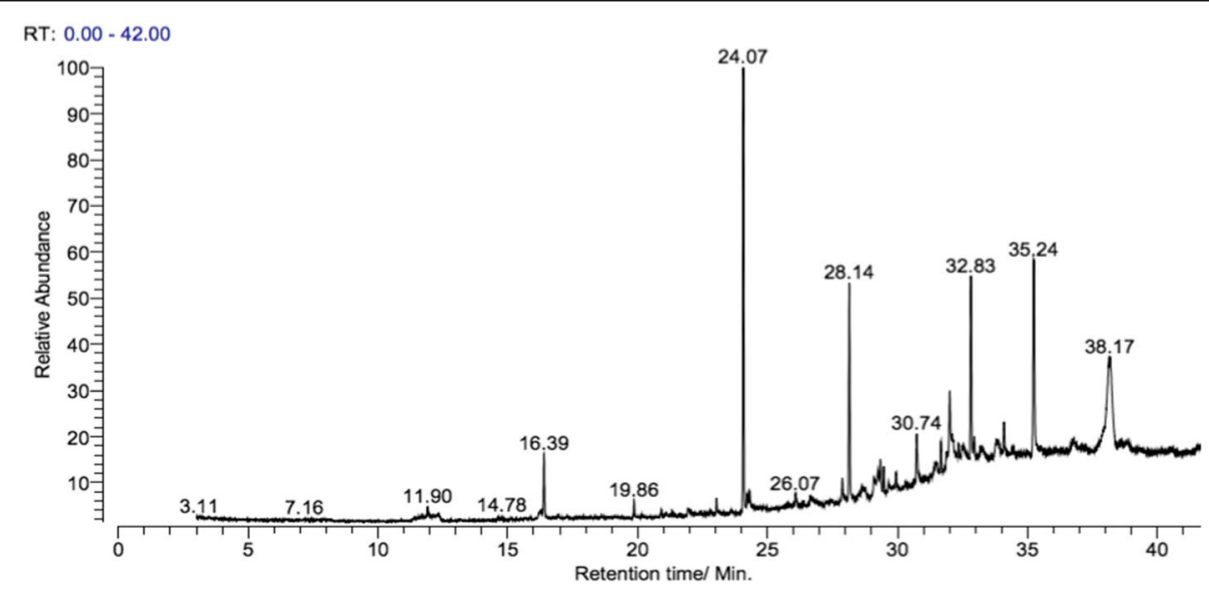

Fig. 5 Gas Chromatography - Mass Spectroscopy (GC-MS) spectrum of ethanol bark extract of Flacourtia indica 

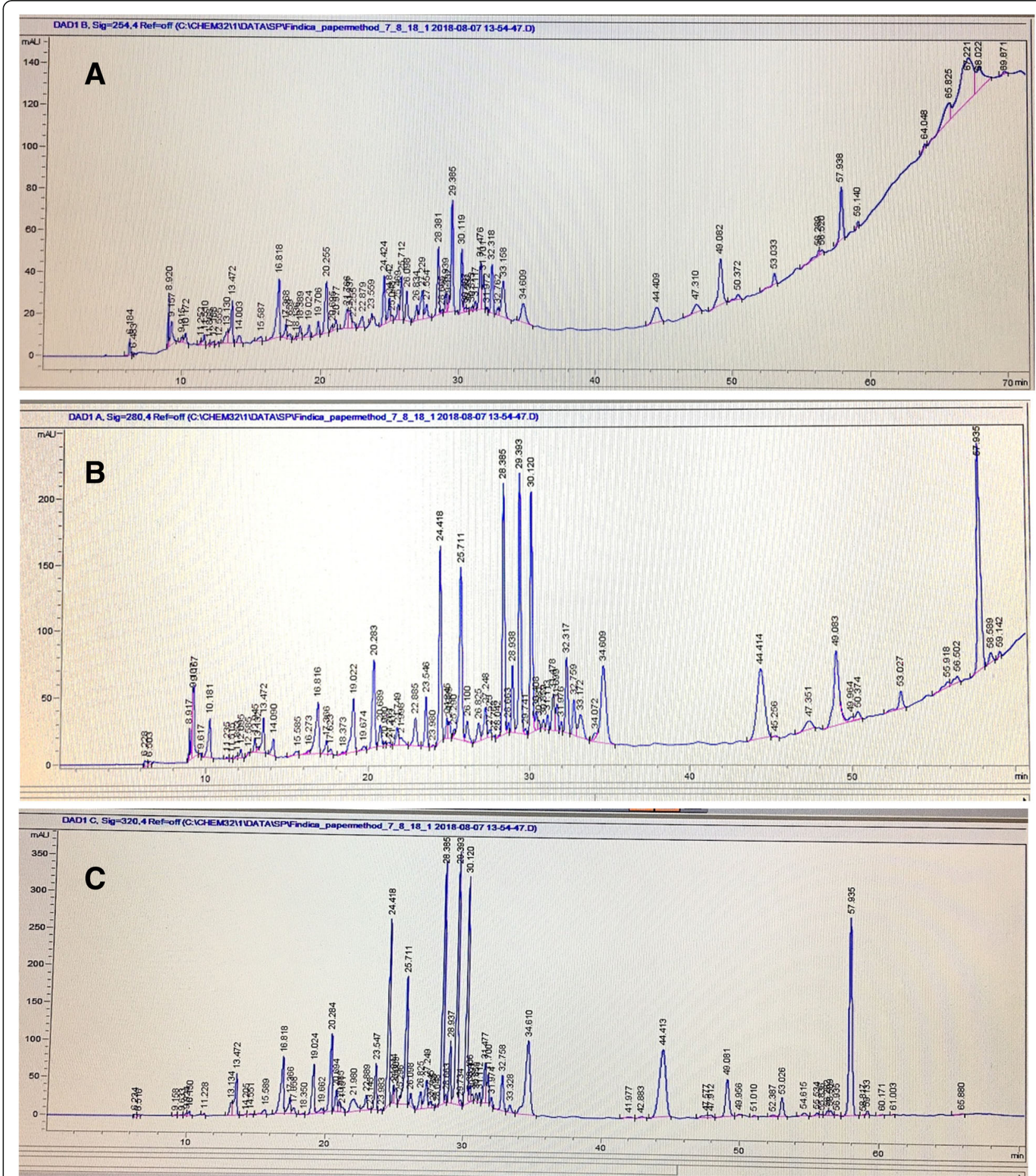

Fig. 6 HPLC chromatogram of ethanol bark extract of Flacourtia indica

\section{Oxidative burst inhibitory activity}

The bark extract of $F$. indicia, showed a pronounced oxidative burst inhibition in comparison to ibuprofen, when tested on PMNs. This observed activity may be due to the inhibition of NADPH oxidize enzyme, which catalyzes the generation of ROS or the direct scavenging of ROS upon the stimulation of opsonized zymosan [31].

\section{Anti-oxidant activity}

The bark extract of C. innophyllum showed the highest DPPH free radical scavenging activity and FRAP over 
other extracts, which may be attributed to the presence of major chemical compounds such as xanthones and coumarins abundantly present in the extracts [23]. C. innophyllum is known as a medicinal plant with number of curative properties and it has been extensively studied worldwide [23]. The present study ascertains the significant free radical scavenging activity of the Sri Lankan variety of C. innophyllum free radical scavenging activity with the means of marked DPPH free radical scavenging and FRAP. Lower chelating properties of the extracts may be due to the low contents of effective metal chelating compounds in the extracts.

ORAC evaluates a hydrogen atom transfer mechanism of anti-oxidants [25]. Significant ORAC of extracts indicates the peroxyl radical absorbance capacities of the extracts at different degrees. The extract of $S$. cochinchinesis showed the highest ORAC over the other extracts as well as the standard green tea extract. The presence of triterpenoids and flavonoid glycosides may be attributed to the anti-oxidant potential of the extracts of $S$. cochinchinesis. It has been extensively studied for its anti-diabetic properties [32].

\section{Total polyphenol and flavonoid contents}

The moderate to weak and non-significant correlations of antioxidant and enzyme inhibitory activities with TPC and TFC (Table 6), respectively suggested that the polyphenolic and flavonoid compounds of the extracts may not be solely responsible for the enzyme inhibitory and antioxidant activities. It is further confirmed by the fact, that the ethanol extract of bark of $F$. indica has exhibited the highest bio-activities irrespective of possessing moderate to low contents of polyphenols and flavonoids (Fig. 4) Among the identified phytoconstitutents, hexadeconoic acid, ethyl ester is known to possess anti-oxidant properties as well as other bio-activities such as hypocholesterolemic, nematicide, pesticide, anti-androgenic, hemolytic and 5-alpha reductase inhibitory properties. Also the compound has flavor properties [33] which may be attributed to the strong aroma of the ethanol bark extract of $F$. indica. Linoleic acid ethylester is another bio-active compound detected in the extract of bark of $F$. indica which is known to possess anti-inflammatory properties and many more of bio-activities including anti-arthritic, anti-histaminic, anti-eczemic and anti-acne properties [33].

\section{Correlation between assays}

The A5-LOX, XO and NO inhibitory activities of plant extracts showed high, negative and significant correlations with DPPH free radical scavenging activity ( $\mathrm{IC}_{50}$ values) $(r=-0.736,-0.728$ and -0.656 respectively at $p<0.01)$ and high, positive and significant correlations with ORAC assay $(r=0.844,0.796$ and 0.696 respectively at $p<0.01$ ). This observation may be indicative of the dual function of bio-actives of plant extracts as free radical, peroxyl radical scavenging and A5-LOX, $\mathrm{XO}$ and $\mathrm{NO}$ production inhibitory compounds. Moreover, the A5-LOX, $\mathrm{XO}$ and $\mathrm{NO}$ inhibitory activities of plant extracts have showed high, positive and significant correlations with each other supporting the fact, that some common group of bio-actives of the extracts could be attributed for the enzyme inhibitory activities of the extracts (Table 6). FRAP of the extracts has showed a high, positive and significant correlation with TPC $(r=0.810, p<0.01)$ so that the FRAP of the extracts may be due to the presence of polyphenols, which are well known to participate in redox reactions.

\section{Gas chromatography - mass spectroscopy (GC-MS) analysis of ethanol extract of bark of Flacoutia indica}

In previous studies the GC-MS analysis of methanol extract of root of $F$. indica has showed the presence of 4-Benzyol-3-methoxyisocoumarin as the major compound [34], which was not detected in the bark extract in this study. No other GC-MS analysis has been previously carried out on any species of the genus Flacourtia except for root of $F$. indica and this is the first report of the GC-MS analysis of Bark of $F$. indica.

\section{Analysis of phenolic compounds using high performance liquid chromatography (HPLC)}

According to a reported study, liquid chromatographymass spectroscopy (LC-MS ${ }^{\mathrm{n}}$ ) analysis of aqueous methanolic fruit extract of $F$. indica has enabled identification of 35 phenolic compounds including rutin, feruloylquinic acid, esculin, gentisic acid glycoside, salicylic acid glycoside and derivatives of caffeolyquinic acids, quercetin and kaempferol [28]. The HPLC peak pattern of the ethanol bark extract of $F$. indica showed similarities with the reported HPLC peak pattern of aqueous methanolic fruit extract of $F$. indica based on the retention times of the peaks under similar experimental conditions. Therefore, the reported compounds of the fruit extract may also be present in the bark extract of $F$. indica. Further, the HPLC chromatogram may be used for standardization of ethanol bark extract of $F$. indica. However, further chemical Characterisation is needed for the identification of the compounds and activity guided fractionation is in progress.

In addition, presence of several other bio-active phytoconstituents including phenolic glycosides [35] coumarins (scoparon) [36, 37] and different types of polyphenolic compounds having radical scavenging properties such as coumaroylglucopyranose, tannins and butyrolactones [38] in the extracts of $F$. indica have been reported. Phenolic glycosides and coumarins have long been recognized as potent A5-LOX and xanthine oxidase inhibitors as well as 
antioxidants [39]. The bark of $F$. indica has been traditionally used to treat rhumatoid arthritis, [40] which is meadiated by inflammation. According to previous studies, The extracts of $F$. indica are known to possess a broad range of pharmacological activities including anti-inflammatory properties [34-36, 41] yet the pharmacological profile needs to be further investigated using more in vivo, in vitro and clinical studies [40]. This is the first report investigating the bio-activities of extract from bark of $F$. indica except for one study in which, the methanol extract of bark of $F$. indica has shown good DPPH free radical scavenging activity $\left(\mathrm{IC}_{50}: 17.5 \pm 1.0 \mu \mathrm{g} / \mathrm{ml}\right)$ [38].

\section{Conclusion}

The extracts showed significant anti-inflammatory activities in vitro in terms of A5-LOX, xanthine oxidase, hyaluronidase and nitric oxide inhibitory activities along with promising anti-oxidant activities. Among the ten extracts, the ethanol extract of bark of $F$. indica showed the highest anti-inflammatory activity with good radical scavenging activities. Therefore, the ethanol extract of bark of $F$. indica is identified as a source of anti-inflammatory agents, which will be further studied to isolate and characterize bio-active constituents.

To the best of our knowledge, through this study, the pro-inflammatory enzyme inhibitory and anti-oxidant potential of ethanol bark extract of $F$. indica was identified and analysed by GC-MS and HPLC for the first time and selected for further bio-logical and chemical characterization.

\section{Compounds studied}

Benzoic acid, ethyl ester, Propan-2-yl tetradecanoate, Estra-1,3,5(10)-trien-17á-ol, Hexadecanoic acid, ethyl ester, Linoleic acid ethyl ester, [1,1'-Bicyclopropyl]-2-octanoic acid, 2 '-hexyl-,methyl ester.

\section{Abbreviations \\ A5-LOX : Arachidonate-5-lipoxygenase; AAPH: Potassium persulphate,2,2- azobis (2-amidinopropane) dihydrochloride; DMEM: Dulbecco's modified Eagle's medium; DMSO : Dimethyl sulfoxide; DPPH: 2,2-diphenyl-2-picryl- hydrazyl; EDTA-Na $\mathrm{Na}_{2}$ : Ethylenediamine tetra acetic acid disodium salt; FCS: Fetal calf serum; FIC: Ferrous ion chelating; FRAP: Ferric reducing antioxidant power; GC-MS: Gas chromatography-Mass spectrometry; HBSS: Hanks Balanced Salt Solution; HPLC: High performance liquid chromatography; LPS: Bacterial lipopolysaccharide,L-NMMA:NG-Monomethyl- L-argininep-dimethylamino benzaldehyde; MTT: 3-(4,5-dimethylthiazol-2-yl)- 2,5-diphenyltetrazoliumbromide; NO: Nitric oxide; ORAC: Oxygen radical absorbance capacity; PDMAB: p-Dimethylaminobenzaldehyde; SOZ: Serum opsonized zymosan; XO: Xanthine oxidase}

\section{Acknowledgements}

The technical staff at Dr. Panjwani Center for Molecular Medicine and Drug Research, International Center for Chemical and Biological Sciences, University of Karachi is highly acknowledged for their support.

\section{Funding}

The National Research Council of Sri Lanka (Grant No: 12-100).

\section{Availability of data and materials}

The data presented in this manuscript belong to the PhD work of Ms. H. D. Sachindra Melshandi Perera and has not been deposited in any repository yet. However, the materials are available to the researchers upon request.

\section{Authors' contributions}

Conception and design of in vitro experiments: HDSMP, JKRRS, SMH, AJ, OVDSJW, MIC. Conducted in vitro experiments: HDSMP. Conception and design of chemical characterisation: HDSMP, JKRRS, HDW. Conducted chemical characterisation: HDSMP, HDW. Data analysis and interpretation: HDSMP, JKRRS, SMH, OVDSJW, AJ. Manuscript drafting: HDSMP. Final approval and critical revision: JKRRS, SMH, OVDSJW, AJ, MIC. All authors read and approved the final manuscript.

Ethics approval and consent to participate

Not applicable for this submission.

\section{Competing interest}

The authors declare that they have no competing interest.

\section{Consent for publication}

Not applicable for this submission.

\section{Publisher's Note}

Springer Nature remains neutral with regard to jurisdictional claims in published maps and institutional affiliations.

\section{Author details}

${ }^{1}$ Industrial Technology Institute (ITI), 363, Bauddhaloka Mawatha, Colombo 07, Sri Lanka. ${ }^{2}$ Institute of Biochemistry, Molecular Biology and Biotechnology, University of Colombo, 90, Cumaratunga Munidasa Mawatha, Colombo 03, Sri Lanka. ${ }^{3}$ Dr. Panjwani Center for Molecular Medicine and Drug Research, International Center for Chemical and Biological Sciences, University of Karachi, Karachi 75270, Pakistan. ${ }^{4} \mathrm{H}$. E. J. Research Institute of Chemistry, International Center for Chemical and Biological Sciences, University of Karachi, Karachi 75270, Pakistan.

Received: 5 October 2017 Accepted: 24 September 2018

Published online: 03 October 2018

\section{References}

1. Sen S, Chakraborty R, Sridhar C, Pradesh A. Free radicals, antioxidants, diseases and phytomedicines: current status and future prospect. Int J Pharm Sci Rev Res. 2010:03:091-100.

2. Pala FS, Gürkan $\mathrm{H}$. The role of free radicals in ethnopathogenesis of disease. Advances in Molecular Biology. 2008;1:1-9.

3. Dobrian AD, Lieb DC, Cole BK, Taylor-Fishwick DA, Chakrabarti SK, Nadler JL. Functional and pathological roles of the12- and15-lipoxygenases. Progress in Lipids Research. 2011;50:115-31.

4. Schneider I, Bucar F. Lipoxygenase inhibitors from natural plant sources. Part 1: medicinal plants with inhibitory activity on Arachidonate 5-lipoxygenase and 5-lipoxygenase/cyclooxygenase. Phytother Res. 2005;19:81-102.

5. González-Peña D, Colina-Coca C, Char CD, Cano MP, Ancos B, SánchezMoreno C. Hyaluronidase inhibiting activity and radical scavenging potential of Flavonols in processed onion. J Agric Food Chem. 2013;61:4862-72.

6. Cheenpracha $\mathrm{S}$, et al. Inhibition of nitric oxide (NO) production in lipopolysaccharide (LPS)-activated murine macrophage RAW 264.7 cells by the norsesterterpene peroxide, epimuqubilin a. Mar Drugs. 2010;8(3):429-37.

7. Yumitha A, Suganda AG, Sukandar EY. Xanthine oxidase inhibitory activity of some Indonesian medicinal plants and active fraction of selected plants. Int J Pharmacy Pharm Sci. 2013;5:293-6.

8. Boukemara, H, Hurtado-Nedelec, M, Marzaioli, V., Bendjeddou, D, El Benna, J, \& Marie, JC, Anvillea garcinii extract inhibits the oxidative burst of primary human neutrophils. BMC Complement Altern Med, 2016:16(1):433.

9. Rates SMK. Plants as source of drugs. Toxicon. 2001;39:603-13. 
10. Arambewela LSR, Wimalasena S, Gunawardene N. Herbal medicine, phytopharmaceuticals and other natural products: trends and advances. 1st ed. Colombo: NAM S\&T Centre, New Delhi and Institute of Chemistry Ceylon; 2006.

11. Perera HDSM, Samarasekara R, Handunnetti S, Weerasena OVDS. In vitro anti-inflammatory and anti-oxidant activities of ten medicinal plants traditionally used to treat inflammatory diseases in Sri Lanka. Ind Crop Prod. 2016;94:610-20.

12. Samaradivakara SP, Samarasekera R, Handunnetti SM, Weerasena OVDSJ. Cholinesterase, protease inhibitory and antioxidant capacities of Sri Lankan medicinal plants. Ind Crop Prod. 2016;83:227-34.

13. Wu MJ, Wang L, Weng CY, Yen JH. Antioxidant activity of methanol extract of the N. nucifera leaf (Nelumbo nucifera gertn.). Chin. Med J. 2003:31(5):987-98.

14. Tappel AL. Methods in enzymology. Academic press, New York. USA. 1962: 539.

15. Sahasrabudhe A, Dedhar M. Anti-hyaluronidase, anti-elastase activity of Garciniaindica. Int J Bot. 2010;6(3):299-303.

16. Lee SK, Mbwambo ZH, Chung H, Luyengi L, Gamez EJ, Mehta RG, Pezzuto JM. Evaluation of the antioxidant potential of natural products. Comb Chem High Throughput Screen. 1998;1 (1):35-46.

17. Min HY, Kim MS, Jang DS, Park EJ, Seo EK, Lee SK. Suppression of lipopolysaccharide-stimulated inducible nitric oxide synthase (iNOS) expression by a novel humulene derivative in macrophage cells. Int Immunopharmacol. 2009;9(7):844-9.

18. Yang EJ, Yim EY, Song G, Kim GO, Hyun CG. Inhibition of nitric oxide production in lipopolysaccharide-activated RAW 264.7 macrophages by Jeju plant extracts. InterdiscipToxicol. 2009;2(4):245-9.

19. Hansen MB, Nielsen SE, Berg K. Re-examination and further development of a precise and rapid dye method for measuring cell growth/cell kill. J Immunol Methods. 1989:119(2):203-10.

20. Mesaik MA, UI-Haq Z, Murad S, Ismail Z, Abdullah NR, Gill HK, et al. Biological and molecular docking studies on coagulin-H: human IL-2 novel natural inhibitor. Mollmmunol. 2006;43:1855-163.

21. Helfand S, Werkmeister J, Roader J. Chemiluminescence response of human natural killer cells. I. the relationship between target cell binding, chemiluminescence and cytolysis. J Exp Med. 1982;156:492-505.

22. Blois MS. Antioxidant determination by use of stable free radical. Nature. 1958;181:1199-200.

23. Benzie IFF, Szeto YT. Total antioxidant capacity of teas by the ferric reducing antioxidant power assay. J Agric Food Chem. 1991:47:633-6.

24. Kim MY. Free radical scavenging and ferrous ion chelating activities of citrus fruits derived from induced mutations with gamma irradiation. Life Sci. 2013;10:401-3.

25. Ou B, Hampsch-Woodill M, Prior RL. Development and validation of an improved oxygen radical absorbance capacity assay using fluorescein as the fluorescent. J Agric Food Chem. 2001;49:4619-26.

26. Singleton VL, Orthofer R, Lamuela-Raventos RM. Analysis of total phenols and other oxidation substrates and antioxidants by means of FolinCiocaltue reagent. Meth Enzymol. 1999;299:152-78.

27. Siddhuraju P, Becker K. Antioxidant properties of various solvent extracts of total phenolic constituents from three different agro climatic origins of drumstick tree (Moringaoleifera lam.) leaves. J Agric Food Chem. 2003;51:2144-55.

28. Alakolanga AGAW, Siriwardene AMDA, SavitriKumar N, Jayasinghe L, Jaiswal R, Kuhnert N. LC-MS ${ }^{n}$ identification and characterization of the phenolic compounds from the fruits of Flacourtia indica (Burm. F.) Merr. And Flacourtia inermis Roxb. Food Res Int. 2014;62:388-96.

29. Torres-Carro R, Isla MI, Thomas-Valdes S, Jiménez-Aspee F, SchmedaHirschmann G, Alberto MR. Inhibition of pro-inflammatory enzymes by medicinal plants from the Argentinean highlands (Puna). J Ethnopharmacol. 2017;205:57-68

30. Akram M, Usmanghani K, Ahmed I, Azhar I, Hamid A, Pak J. Comprehensive review on therapeutic strategies of gouty arthritis. Pharm Sci. 2014;27:1575-82.

31. Mahomoodally $F$, et al. In vitro modulation of oxidative burst via release of reactive oxygen species from immune cells by extracts of selected tropical medicinal herbs and food plants. Asian Pac J Trop Med. 2012;5:440-7.

32. Rashed KN. Antioxidant activity from Diospyros Ebenum stems extracts and phytochemical profile. JAIS. 2013;1:70-2.

33. Duke's Phytochemical and Ethnobotanical Databases U.S. Department of Agriculture, Agricultural Research Service 992-1996. [Online]. Available: http://phytochem.nal.usda.gov [Accessed 12 July 2017].
34. Eramma N, Devaraja G. Antibacterial potential and phytochemical analysis of Flacourtia indica (Burm.F.) Merr. Root extract against human pathogens. Indo Am J Pharm Res. 2013;3:3832-46.

35. Kamatou GPP, Viljoen AM, Steenkamp P. Antioxidant, anti-inflammatory activities and HPLC analysis of south African Salvia species. Food Chem. 2010;119:684-8

36. Nazneen N, Mazid MA, Kundu JK, et al. Protective effects of Flacourtia indica aerial parts extract against paracetamol-induced hepatotoxicity in rats. J Taibah Univ Sci. 2009:2:1-6.

37. Jang SI, Kim YJ, Lee WY, et al. Scoparone from Artemisia capillaris inhibits the release of inflammatory mediators in RAW 264.7 cells upon stimulation cells by interferon-gamma plus LPS. Arch Pharm Res. 2005;28:203-8.

38. Swati M, Nath SG, Yatendra K, Kanchan K, Mohan SR, Prakash O. Phytochemical analysis and free-radical scavenging activity of Flacourtia indica (Burm. F.) Merr. J Pharm Res. 2009:8:81-4.

39. Werz O. Inhibition of 5-lipoxygenase product synthesis by natural compounds of plant origin. Planta Med. 2007:73:1331-57.

40. Ancy P, Padmaja V, Radha K, Jomy J, Hisham A. Diuretic activity of the roots of Flacourtia indica. Hygeia J D Med. 2013;5:79-83.

41. Kundu J, Roy M, Bachar SC, Chun KS, Kundu JK. Analgesic, antiinflammatory, and diuretic activity of methanol extract of Flacourtia indica. Arch Basic Appl Med. 2013;1:39-44.

42. Jayaweera DMA, Senaratna LK. Medicinal plants (indigenous and exotic) used in Ceylon. Part II. National Sci Found. 2006;69.

43. Su CR, Kuo PC, Wang ML, Liou MJ, Damu AG, Wu TS. Acetophenone derivatives from Acronychia pedunculata. J Nat Prod. 2003:66:990-3.

44. Prabakaran K, Britto J. Biology, agroforesty and medicinal value of Calophyllum inophyllum L. (Clusiaceae): a review. J Asian Nat Prod Res. 2012;1:24-33.

45. Vadivu R, Lakshmi KS. In vitro and in vivo anti-inflammatory activity of leaves of Symplocos cochinchinensis (Lour) Moore ssp Laurina. Bangladesh J Pharmacol. 2008:3:121-4.

46. Jayaweera DMA, plants M. (indigenous and exotic) used in Ceylon. Part IV. National Sci Counc Sri Lanka. 1982:81

47. Patro SK, Behera PC, Kumar PM, Sasmal D. Pharmacological review of Flacourtia sepiaria. SAJP. 2013;2:89-93.

48. Jain D, Baheti AM, Jain SR, Khandelwal KR. Use of medicinal plants among tribes in Satpursa region of Dhule and Jalgaon district of Maharastra- an ethnobotanical survey. Indian J Tradit Know. 2010;9:152-7.

49. Samaranayake GVP, Pushpakumara AAJ. A literary review on traditional medical systems for bone fractures in Sri Lanka. IJTRD. 2016;3:534-6.

50. Jayaweera DMA, Senaratna LK. Medicinal plants (indigenous and exotic) used in Ceylon. Part II. National Sci Found. 2006;89.

Ready to submit your research? Choose BMC and benefit from:

- fast, convenient online submission

- thorough peer review by experienced researchers in your field

- rapid publication on acceptance

- support for research data, including large and complex data types

- gold Open Access which fosters wider collaboration and increased citations

- maximum visibility for your research: over $100 \mathrm{M}$ website views per year

At BMC, research is always in progress.

Learn more biomedcentral.com/submission 